\title{
電気粘性流体を用いた液圧制御弁* (圧力制御弁への応用)
}

\author{
横 田貞 - $^{* 1}$, 近 藤

\section{A Control Valve by Making Use of an Electro-rheological Fluid (Application to Pressure Control Valves)}

豊*2

\author{
Shinichi YOKOTA and Yutaka KONDOH
}

\begin{abstract}
Electro-rheological (ER) fluids change their apparent viscosity according to the electric field strength. Using ER fluids, it is possible to directly interface between electric signals and fluid power without moving parts. This study aims at practical applications of ER fluids to fluid power systems, especially to control valves (ER valves). In this paper, first, static characteristics of a two-port ER valve is experimentally clarified to obtain basic characteristics of ER valves. Secondly, making the best use of the features of the ER valve, a three port pressure control valve using ER fluids is proposed and manufactured. Static and dynamic characteristics of the manufactured pressure control valve are measured. Thirdly, using the manufactured pressure control valve, a one-link manipulator with FHA (Flexible Hydraulic Actuator) is driven. As a result, it is experimentally confirmed that the pressure control valve using ER fluids is applicable to use in driving actuators.
\end{abstract}

Key Words: Fluid Power System, Control Valve, Electro-rheological Fluid, ER Valve, Pressure Control Valve, Flexible Hydraulic Actuator, Dynamic Characteristics

\section{1. まえがき}

電気粘性流体または ER 流体(Electro-rheological Fluid)と呼ばれる, 外部電界をかけると著しく粘性が 変化する流体があり,このような効果を電気粘性効果 または ER 効果と呼ぶ。電気粘性流体は均一系電気粘 性流体と粒子分散系電気粘性流体に大別されるが, 粒 子分散系電気粘性流体の ER 効果は，絶縁油に固体粒 子を混ぜると外部電界により固体粒子が誘電分極を起 こし鎖状構造を形成することにより起こると考えられ ている。㫣気粘性流体を用いることで可動部なしに電 気信号で直接, 流体の流れを制御することが可能とな り, 単純棈造で高信頼, 高応答, 高機能な流体機械の 開発が期待される。近年になって無機・有機複合粒子 を絶縁油に混ぜた電気粘性流体(1) が開発され, 耐熱 性, 酎久性, 温度依存性といった問題がかなり改善さ れた。しかも ER 効果によるせん断応力が大きく消費 電力は小さいことから電気粘性流体の実用化が期待さ れている。本研究は無機・有機複合粒子を用いた電気

* 原稿受付 1996 年 2 月 15 日.

*1 正員, 東京工業大学精密工学研究所 (- 226 横浜市緑区長津 由町 4259).

*2 让員, 東京工業大学大学院.
粘性流体の液圧回路システムへの応用，とくに液圧制 御弁(以下 ER バルフとと呼ぶ)への応用を目的とする。

電気粘性流体を液圧回路システムへ応用したこれま での研究としては, Strandrud ${ }^{(2)}$ がピストンシリンダ 内に電極をもうけ電気粘性流体を応用したアクチュエ ー夕を試作し，振動試験機に応用している。また， Simmonds ${ }^{(3)}$ は四組の電極でブリッジを構成し，ダイ ヤフラムを用いたシリンダを動かしている．田中ら(4) は二組の電極を直列につなぎ，その間を制御ポートと し電気粘性流体によりコム人工筋を駆動している。ま た, ダンパ(5)(6)やクラッチ(7)への応用研究もなされて いる.しかし、これらこれまでの研究で電気粘性流体 の可能性がすべて検討されたとは言えない．特に液圧 回路システムへの応用に関しては十分な応用研究がな されておらず，まだ多くの可能性が残されていると思 われる.

本論文ではまず 2 ポート ERバルブを試作し，流量， バルブ両端に生じる差圧, 印加電圧間の静特性を実験

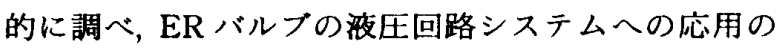
可能性を検討している. 次に本研究では $\mathrm{ER} ハ$ バルブは 圧力制御弁に適した特性をもっていることに着目し， 電気粘性流体を用いた圧力制御弁（以下，压力制御 ER バルブと呼ぶ)を提案および試作し，さらに試作した 
圧力制御 $\mathrm{ER}$ バルブを用いて実際に一軸マニピュレー タを駆動した。

\section{2. 奄気粘性流体および 2 ポート ERバルブ}

2・1 電文粘性流体本研究で使用している電気 粘性流体(1) は図1に示すように, 絶縁油に, ER 効果 を引き起こす固体粒子(ER 粒子)を混ぜた粒子分散系 電気粘性流体である。絶縁油には ER 粒子と比重を合 わせるため高比重シリコンオイルを使用し, ER 粒子 としてポリマ粒子の表面を特殊酸化チタンの微粒子で 被覆した無機・有機複合粒子を $30 \%$ wt. で分散させて いる．分散後の粘度は $65 \mathrm{mPa} \cdot \mathrm{s}$ である．また， ER 粒 子径は $16 \mu \mathrm{m}$ 程度である. 無機・有機複合粒子を用い た電気粘性流体は, 複合粒子が低比重のため分散媒を ほほ同じ比重にすることが可能なことから耐沈降・分 散安定性に優れている，複合粒子は柔軟材を多く用い ているため, 電極板などを摩耗する心配もない。また， 作動温度範囲が広く，低電流形であるなどの特長をも ว.

$2 \cdot 22$ ポートERパルフ 電気粘性流体は, 図 2(a)に示すように電極間に電界をかけると ER 粒子 が誘電分極を起こしクラスタを形成する。図 2(b)の ように電気粘性流体を電極間に流した状態で電極間に 電界をかけると,このクラス夕の発生により電極間に

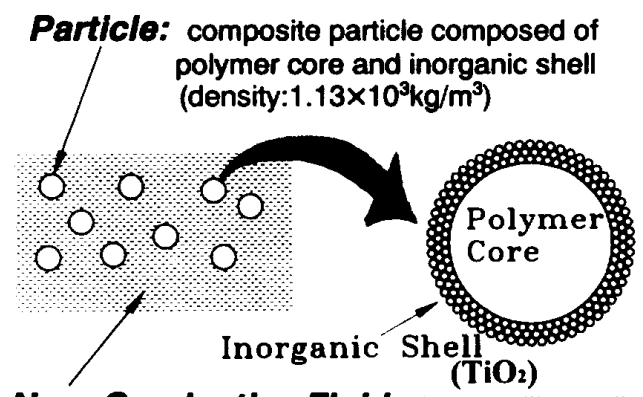

\section{Non-Conductive Fluid : heavy silicon oil (density: $1.13 \times 10^{3} \mathrm{~kg} / \mathrm{m}^{3}$ ) \\ Concentration of particles : $30 \% \mathrm{wt}$}

Fig. 1 Electro-rheological fluid developed by Fujikura Kasei Co. Ltd. (a)

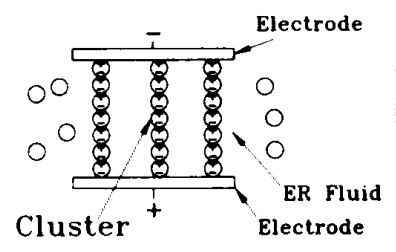

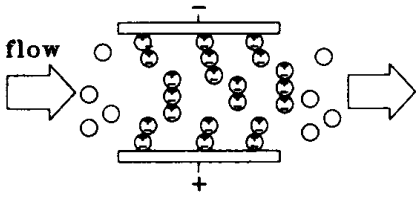

High Resistance

(b)
Fig. 2 Principle of ER valves
おいて流れに対し大きな抵抗が発生し，見かけ上粘度 が増す(8). ER バルブはこの現象を利用し，流れを制御 しょうとするものである.

本研究ではまず基本特性を明らかにする目的で, 電 極間に電気粘性流体を流し，電界強度を一定としたと きの差圧-流量間の静特性を実験により測定した.電極 は 12 層の平行平板電極で構成されており，電極間隔 は $0.5 \mathrm{~mm}$, 長さ $40 \mathrm{~mm}$, 幅 $26 \mathrm{~mm}$ である. 電極の総 面積は $125 \mathrm{~cm}^{2}$ となる。実験ではまず電極間に電気粘 性流体を $40 \mathrm{~cm}^{3} / \mathrm{s}$ 流し，その状態で一定電圧を印加 し徐々に流量を減らしながら差圧を測定した。測定は $40 \mathrm{~cm}^{3} / \mathrm{s}$ から $5 \mathrm{~cm}^{3} / \mathrm{s}$ の間を 3 往復して行った. 測定 結果を図 3(a) に示す.図 3(a)の結果より電界強度に より差圧が変化しているのがわかる，また, 特徴的なこ ととして, 流量に依存せずほほ一定の差圧を生じている のがわかる。これは均一系電気粘性流体にはない粒子 分散系電気粘性流体の特徴でもある。粒子分散系電気

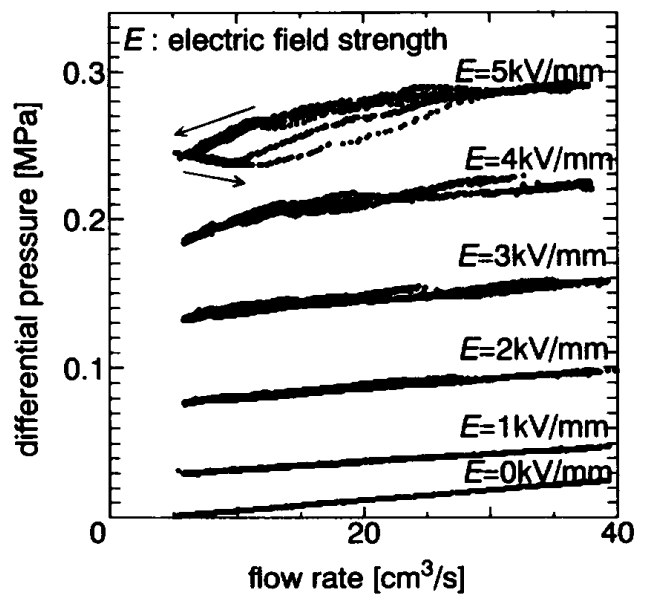

(a) Static characteristics between differential pressure and flowrate (flowrate of $40 \mathrm{~cm}^{3} / \mathrm{s}$ to $5 \mathrm{~cm}^{3} / \mathrm{s}$ )

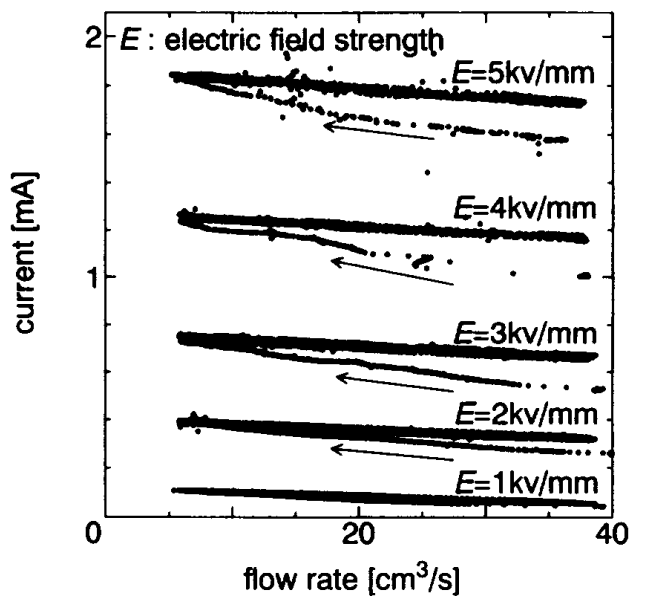

(b) Static characteristics between current and flowrate (flowrate of $40 \mathrm{~cm}^{3} / \mathrm{s}$ to $5 \mathrm{~cm}^{3} / \mathrm{s}$ )

Fig. 3 
粘性流体は，ビンガムプラスチック流体によく近似(9) されるが，ER 効果による抵抗が粘性による抵抗より 十分大きいため流量によらずほほ一定の差圧が生じて いると考えられる．本研究ではこの特性に着目し，後 で述べる圧力制御 ER バルブではこの特性を積極的に 利用する. 図 3(b)kERバルブの電流-流量間の静特 性の結果を示す。これは図 3(a) の測定と同時に測定 した結果である.最初の 1 往復めにはヒステリシスが 見られるがそれ以後ヒステリシスは存在しない. 流量 の減少とともに若干ではあるが, 電流が増している. 電界強度 $3 \mathrm{kV} / \mathrm{mm}$ のときで $0.7 \mathrm{~mA}$ 程度電流が流れ ているが，これは単位面積当たりにすると $5.6 \mu \mathrm{A} /$ $\mathrm{cm}^{2}$ であり低電流であることがわかる。

次に, 流量を $0 \sim 40 \mathrm{~cm}^{3} / \mathrm{s}$, つまり電気粘性流体を せき止める状態まで変化させたときの差圧-流量間の 静特性例を図 4 に示す.差圧一流量間にかなりのヒステ リシスが確認される。電気粘性流体はひとたび固化し た状態(流量零)になると崩壊しにくくなり，かなりの 差压に耐える. 固化した電気粘性流体が差圧により崩 壞した後でも固化前の状態にはもどらないこともわか る.この傾向は電界が強いほど顕著になることを経験 している．何度か測定を繰返したが固化した電気粘性 流体が崩壊する差圧はばらついた。この結果から液圧 回路システムに, ERバルブを応用する際は, 流量が 零の状態になるまで ER バルブを使用するのは一般的 には避けるべきであると考えられる。

\section{3. 圧力制御 ER バルフ}

$3 \cdot 1$ 槽造 圧力を制御したい要求から, 圧力制 御弁と呼ばれる弁がある。負荷流量と無関係に負荷圧 力を制御できる弁を一般的に区力制御弁と呼ぶ。また,

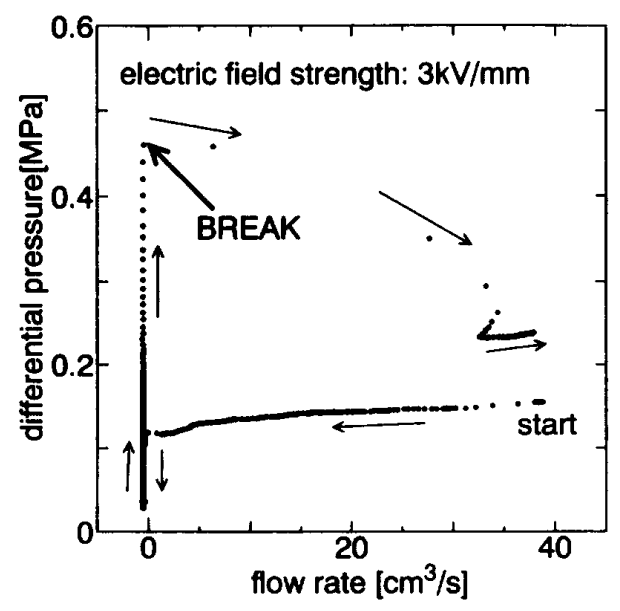

Fig. 4 Static characteristics between differential pressure and flowrate (flowrate of $40 \mathrm{~cm}^{3} / \mathrm{s}$ to $0 \mathrm{~cm}^{3} / \mathrm{s}$ )
サーボ系に応用できるものは圧力制御サーボ弁とも呼 ばれる。この圧力制御弁は負荷圧力をフィードバック するような，機械的な機粠または液圧回路を内部に構 成し，一般的に複雑な構造となっている．前述の図 3(a)に示すように ER バルブでは粘性抵抗による圧 力降下よりも ER 効果による圧力降下が大きいため流 量によらずほほ一定の差圧を生じている。電気粘性流 体のこの特性を積極的に利用することにより，圧力制 御弁を単純構造で容易に実現できる可能性があること から, 本研究では圧力制御 $\mathrm{ER}$ バルブの試作を試み た。試作した圧力制御 ER バルプの構成を図 5 に示す。 構成は固定オリフィスと 2 ポート ER バルブを直列に 組合せそその間を制御ポートとした 3 ポート形であ る. 固定オリフィス部も同じ 2 ポート $\mathrm{ER}$ バルブとし ないのは, 2 ポート $\mathrm{ER}$ バルフの特性が電極間通過流 量によらず一定の差圧を生じるとすると, 仮に固定才 リフイス部を同じ 2 ポート ERバルブとしても，負荷 圧力は下流側の 2 ポート ER バルフ電極間の電界強度 によってのみ決まるためである.

$3 \cdot 2$ 設計手順 圧力制御 $\mathrm{ER}$ バルブの設計に際 しては電極寸法が不適切だと粘性抵抗の影響が大きく なり図3(a)のようなフラットな特性にはならない。 また, ER 効果による抵抗に比べ粘性抵抗が大きいと ER 効果による粘性の変化率が小さくなり好ましくな い. 本研究では以下の手順で電極の設計を行った。

圧力制御弁の性能指標として, 最大負荷流量 $Q_{L \text {,max }}$ 最高負荷圧 $P_{L, \text { max }}$ および最高負荷流量時の制御圧の 変動率 $\left|\Delta P_{L}\right| / P_{L, \max }$ を挙げる.ここで負荷流量 $Q_{L}$, 負 荷圧力 $P_{L}$ とは図 5 中に示すように, 制御ポートにつ ながれた負荷に流れ込む(または負荷から流れ込む)流 量および負荷に加えられる圧力のことである。また負

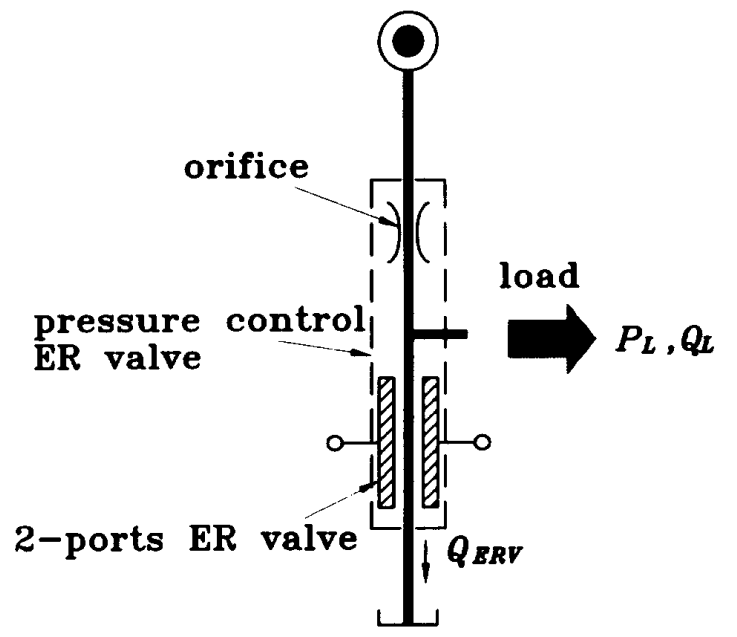

Fig. 5 Schematic of the manufactured pressure control ER valve 
荷圧力変動 $\left|\Delta P_{L}\right|$ は負荷流量の増加（または低下）によ る負荷圧力の低下分 (または增加分)のことである。本 研究では,これら与えられた性能指標をみたすべく， 以下に示す簡単な設計モデルを用いて電極寸法を決定 した。

電極間に一定の電界強度を与え，流れをせき止めた 状態から差圧を上げていき，2 ポート ER バルブが流 れ始める圧力を $P_{y}$ とすると力の釣合いから

$$
P_{y, \max }=\frac{2 L}{H} \sigma_{y, \max }
$$

となるここで，Lは電極長さ(流れ方向),$H$ は電極 間隔， $\sigma_{y, \text { max }}$ は電気粘性流体の最大降伏応力である。一 方，電極間通過流量の変化に対する 2 ポート ER バル ブ差圧の変化 $\Delta P$ についてであるが, 図 3(a) の静特 性を参考にすると無電界時のグラフの傾きと有電界時 のグラフの傾きにそれほどの違いがないことから，有 電界時も無電界時も流量変化に対する差压の変化 $\Delta P$ は同じであると近似する。さらに無電界時の電極板間 の流れを，助走区間を無視した平行平板間の粘性流れ だとすると

$$
\Delta P=\frac{12 \mu L}{W H^{3}} Q_{\mathrm{ERV}}
$$

となる。ここで， $\mu$ は無電界時の電気粘性流体の粘度, $W$ は電極幅(流れに垂直方向)，QERV は電極間通過流 量である。式(1)，(2)より設計パラメータである $P_{L, \max }$ と $\left|\Delta P_{L}\right| / P_{L, \max }$ 扔よび $Q_{L}-P_{L}$ 間静特性モデルを

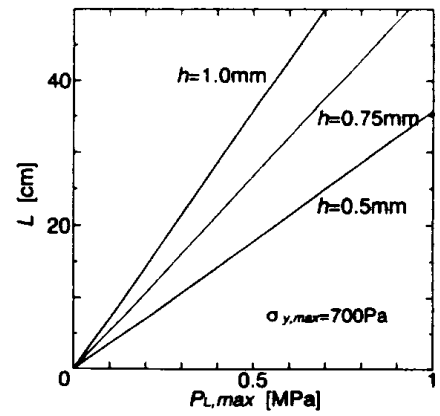

Fig. 6 Relation between $L$ and $P_{L, \max }$

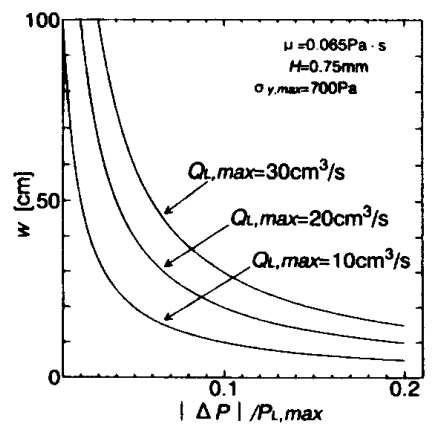

Fig. 7 Relation between $W$ and $\left|\Delta P_{L}\right| / P_{L, \max }$

$$
\begin{aligned}
& P_{L, \max }=P_{y, \max }=\frac{2 L}{H} \sigma_{y, \max } \\
& \frac{\left|\Delta P_{L}\right|}{P_{L, \max }}=\frac{1}{P_{L, \max }} \frac{12 \mu L}{W H^{3}}\left|\left(\Delta Q_{\mathrm{ERV}}\right)_{\max }\right| \\
& =\frac{1}{P_{L, \max }} \frac{12 \mu L}{W H^{3}}\left|Q_{L, \max }\right| \\
& P_{L}=\frac{2 L}{H} \sigma_{y}(E)+\frac{12 \mu L}{W H^{3}} \Delta Q_{\mathrm{ERV}} \\
& =\frac{2 L}{H} \sigma_{y}(E)-\frac{12 \mu L}{W H^{3}} Q_{L}
\end{aligned}
$$

とする。ただし，式（4），(5)の導出過程において，負 荷圧力変動 $\left|\Delta P_{L}\right|$ は $\left(P_{S}-P_{L}\right)$ より十分小さいとし， $\Delta Q_{\mathrm{ERV}}=-Q_{L}$ と近似している.

式(3)，（4）を用いて電極寸法 $L, W, H$ を決定す る。決定手順は以下のとおりである。まず使用する電 源の最高電圧から比較的自由度のない $H$ を決め, 次 に式（3）を用いて $L$ を決定し最後に式（4)より $W$ を 求める．参考までに $\sigma_{y, \max }=700 \mathrm{~Pa}$ としたときに式 $(3)$ 上り得られる $L-P_{L, \max }$ 間の特性図を図 6 に示す。 また, $\mu=0.065 \mathrm{~Pa} \cdot \mathrm{s}, H=0.75 \mathrm{~mm}, \sigma_{y, \max }=700 \mathrm{~Pa}$ と したときに式 ( 4 ) より得られる $W-\left|\Delta P_{L}\right| / P_{L, \max }$ 間の 特性図を図 7 に示す，定性的には，流れ方向の電極長 さが長く電極間隔が狭いほど高い負荷圧力を得ること が可能となる．また，幅および電極間隔が広いほど負 荷流量の変化に対する負荷圧力の変化は小さくなる.

本研究では最大負荷流量 $Q_{L, \max }$ は $10 \mathrm{~cm}^{3} / \mathrm{s}$, 最大 負荷圧力 $P_{L, \text { max }}$ は $0.5 \mathrm{MPa}$ ，負荷流量の変化に対す る負荷圧力の変化は $1 \mathrm{~cm}^{3} / \mathrm{s}$ あたり $5 \mathrm{kPa}$ $\left(\left|\Delta P_{L}\right| / P_{L, \max }=0.1\right)$ とし電極寸法を決定した。また, 式 (3)，（4）中の $\sigma_{y, \max }$ は図 $3(\mathrm{a})$ の静特性を参考にし

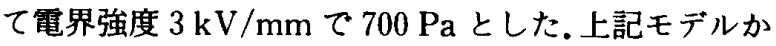
ら電極寸法を見積もり，試作した圧力制御 ER バルフ の断面図を図 8 に示す.ここでは, 電極は長さ $L$ (流れ

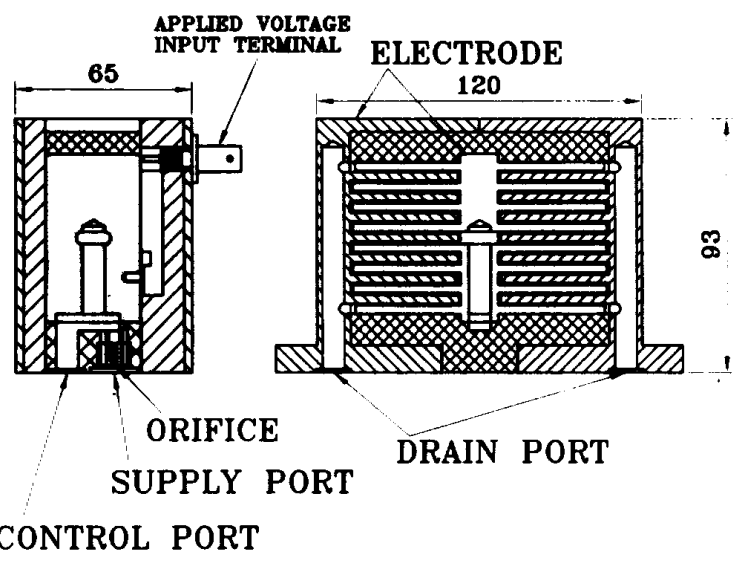

Fig. 8 Sectional view of the manufactured pressure control ER valve 
方向 $)=300 \mathrm{~mm}$, 幅 $W($ 流れに垂直方向 $)=35 \mathrm{~mm}$, 電 極間隔 $H=0.85 \mathrm{~mm}$ (設計值は $0.75 \mathrm{~mm}$ )のものが四 組並列に組込まれている．電極の長さが長いため電極 形状はくし状とした。

一方, 固定オリフィス部については, 図 4 の結果か らわかるように電極間には電界強度および負荷流量に よらず，動作中は常に電気粘性流体が電極間に流れて いる必要がある。そのためにはオリフィス径は大きい ほどよいが, 必要以上に大きいとエネルギーの損失が 多くなってしまうのて好ましくない。また, 無電界時 の負荷圧力が大きくなってしまうことや，電極間にお ける流速が速くなると ER 効果が低下寸ることからも 必要以上にオリフィス径を大きくするのはさけるべき であり適当なオリフィス径を選ぶ必要がある．広く知 られているオリフィスに関する式がこの ER 流体にも 使用できると仮定して, 供給圧を $P_{s}$, 電極間の通過流 量を $Q_{\mathrm{ERV}}$ ，オリフィス面積を $A_{\text {or }}$ とすると次のような 近似式を得る。

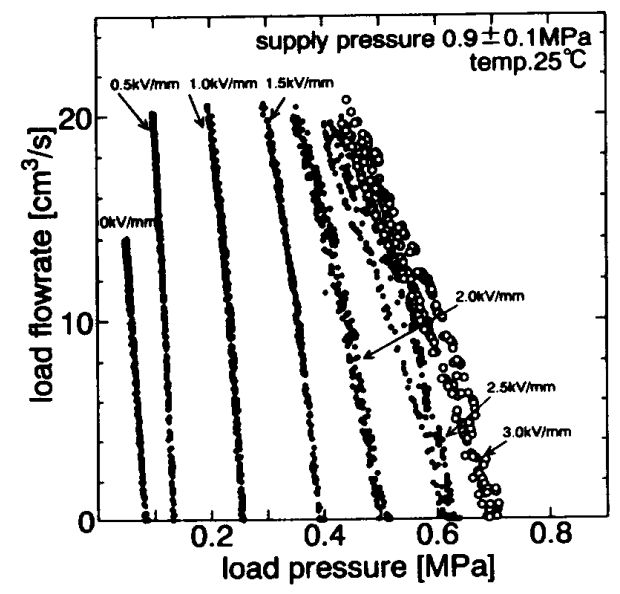

(a) Experiment

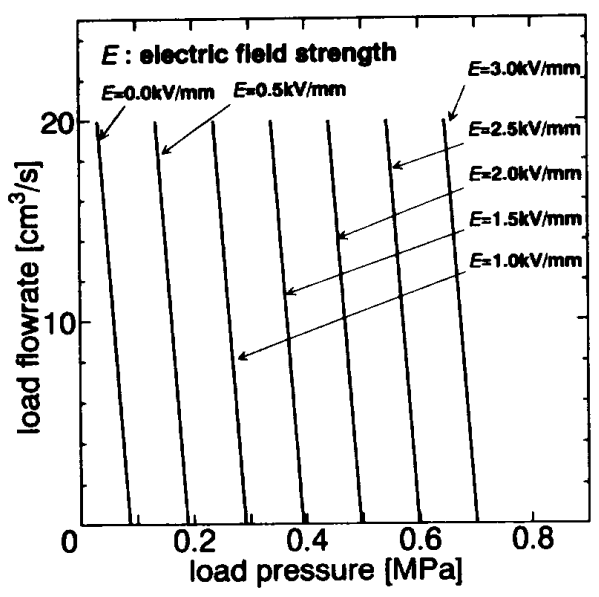

(b) Model

Fig. 9 Static characteristics between load flowrate and load pressure

$$
Q_{\mathrm{ERV}, \min }=c A_{o r} \sqrt{\frac{2\left(P_{S}-P_{L, \max }\right)}{\rho}}-Q_{L, \max }
$$

ここで $c$ は流量係数 $(=0.5), \rho$ は電気粘性流体密度 $\left(=1.1 \times 10^{3} \mathrm{~kg} / \mathrm{m}^{3}\right)$ である. 本研究では供給圧力 $P_{S}=$ $0.9 \mathrm{MPa}$, 最大負荷圧力 $P_{L, \max }=0.5 \mathrm{MPa}$, 最大負荷流 量 $Q_{L, \max }=10 \mathrm{~cm}^{3} / \mathrm{s}$ とし最大電極間通過流量 $Q_{\mathrm{ERV}, \mathrm{m} / \mathrm{n}}$ が $10 \mathrm{~cm}^{3} / \mathrm{s}$ 程度になるようにオリフィス面積 $A_{\text {or }}$ を $1.4 \times 10^{-6} \mathrm{~m}^{2}$ (オリフィス径 $\phi 1.3 \mathrm{~mm}$ )とした.ちな みに供給圧力およびオリフィス面積を上記のようにす ると無電界時の負荷压力 $P_{L, m i n}$ は $7.4 \times 10^{4} \mathrm{~Pa}$ と見積 もられる.

$3 \cdot 3$ 考察 上記モデルから電極面積および消費 電力について考察する。まず, 電極面積 $A_{E L}$ は式 ( 3 ), (4)より

$$
A_{E L}=W L=\frac{3 \mu P_{L, \max } Q_{L, \max }}{\sigma_{y, \max }^{2}\left(\frac{\left|\Delta P_{L}\right|}{P_{L, \max }}\right)} \times \frac{1}{H}
$$

となる.式（7）より，同じ電気粘性流体 $\left(\mu, \sigma_{y, \max }\right.$ が同 じ值)で压力制御 $\mathrm{ER}$ バルブの性能が同じ（ $Q_{L, \max }$, $P_{L, \max },\left|\Delta P_{L}\right| / P_{L, \max }$ が同じ値)だとすると電極間隔を 広くすると同じ䑤界強度を実現するのに高電压源が必 要となるが電極面積が小さくなることがわかる.この ことから許容範囲で電極間隔はなるべく広くとるほう が,バルブをコンパクトにまとめるためには望ましい ことがわかる。

また，電気粘性流体の抵抗率を $\gamma$ とすると式 $(7)$ よ り最大消費電力 $P_{\max }$ は

$$
P_{\max }=\frac{\left(E_{\max } H\right)^{2}}{\gamma \frac{H}{W L}}=\frac{3 \mu P_{L, \max } Q_{L, \max } E_{\max }^{2}}{\sigma_{y, \max }^{2}\left(\frac{\left|\Delta P_{L}\right|}{P_{L, \max }}\right) \gamma}
$$

となる.ここで $E_{\max }$ は使用時の最大電界強度である. 電気粘性流体および圧力制御 $\mathrm{ER}$ バルフの性能が同じ であるとすると電極寸法によらず消費電力は同じにな ることが式(8)よりわかる.

$3 \cdot 4$ 觧特性図9(a)に試作した压力制御 ER バルブの負荷流量-負荷圧力間の静特性を実験により 測定した結果を示す.負荷圧力が最大 $0.7 \mathrm{MPa}$ 程度生 じている．また，負荷流量によらずほほ一定の負荷圧 力が得られているのがわかる。電界強度が $2.5 \mathrm{kV} /$ $\mathrm{mm} \sim 3.0 \mathrm{kV} / \mathrm{mm}$ で実験データにばらつきが見られ る.これは電極間に流れる流量が少ないためにおこる 現象ではないかと考えられる，同じような現象は図 3(a)の 2 ポートERバルフの静特性測定結果にも現 れている. 図9(b)には式（5)のモデルより得られる 負荷流量一負荷王力間の静特性を示す.ただし, 無電界 
時の負荷圧力 $(0.087 \mathrm{MPa})$ を式 ( 5 ) より得られる負荷 圧力に加え補正している。また，式（5)において $\sigma_{y}(E)$ は，実験結果の最大負荷圧力と比較的一致する ように $0.29 E$ とした. 設計モデルの近似が原因で図 9(a)，（b）に多少の違いは生じているが, 式(3) 〜 (5)が設計モデルとしては十分満足できるモデルで あることがわかる。

図 10 には制御ポートをブロックし負荷流量を零と したときの負荷压力-電界強度間の特性つまり圧力ゲ イン特性を示す，ほほ電界強度に比例して負荷压力が 変化している。この特性は圧力制御 $\mathrm{ER}$ バルブがサー

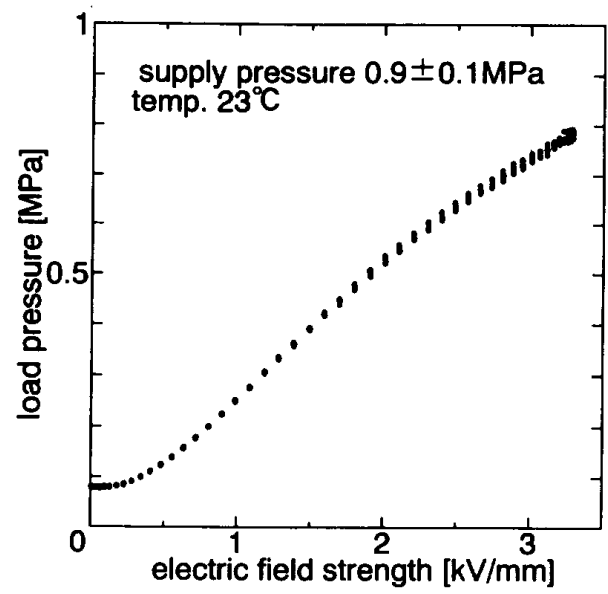

Fig. 10 Static characteristics between load pressure and electric field strength

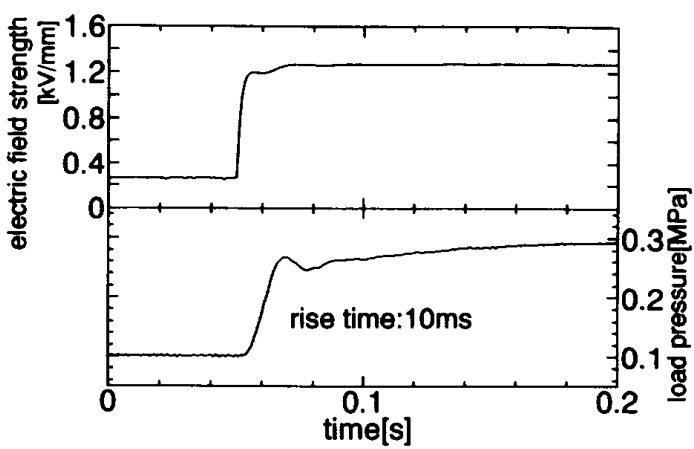

(a)

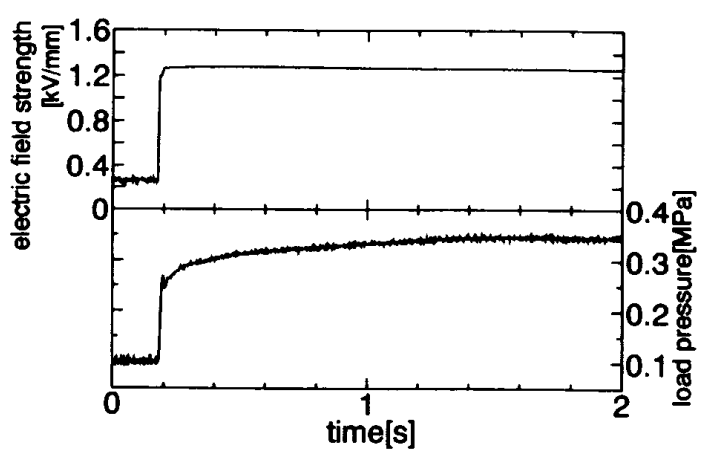

(b)

Fig. 11 Step response of the pressure control ER valve
ボ系への応用に適していることを示している。

3.5 功特性 図11(a)に試作した圧力制御 ER バルブの電界強度をステップ状に変化させたときの負 荷圧力の応答波形を示す．測定は制御ポートをブロッ クし負荷流量を零とした状態で行った。立上り時間 10 ms という結果が得られた。しかし時間軸を長くした 負荷圧力のステップ応答波形図 11 (b) からわかるよ うに速い立上りで応答しているが，その後ゆっくりと 負荷圧力が上昇している．この現象は ER 奻果のメ力 ニズムに起因するのではないかと考えており，今後詳 しく検討する予定である.

図 12 には $900 \mathrm{~V} / \mathrm{mm}$ を中に振幅 $500 \mathrm{~V} / \mathrm{mm} て$ 正弦波状に電界強度を変化させ, 調和解析により電界 強度-負荷圧力間の周波数応答特性を測定した結果を 示す.図 13 には例として電界強度を $10 \mathrm{~Hz}$ の正弦波 状に変化させたときの負荷圧力の応答波形を示す。測 定ではステップ応答同様に制御ポートをブロックして 行った.図 12 の結果より試作した圧力制御 ER バルフ はバンド幅が $30 \mathrm{~Hz}$ 程度あり液圧サーボ系への応用 も可能であることがわかる。

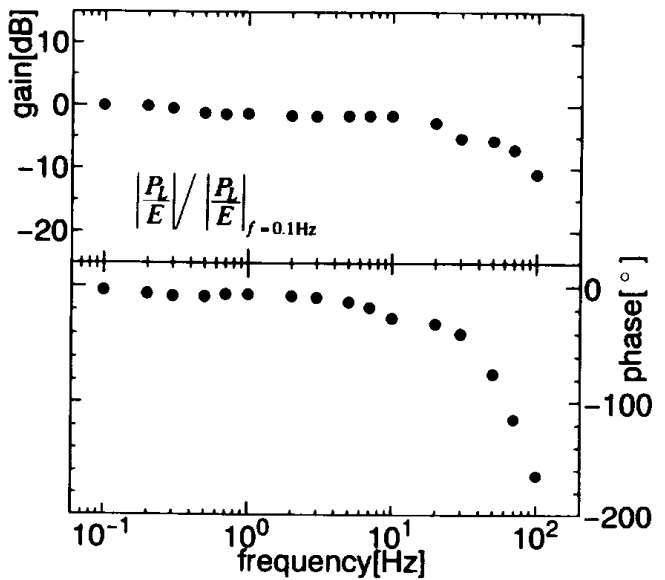

Fig. 12 Frequency characteristics between load pressure and electric field strength

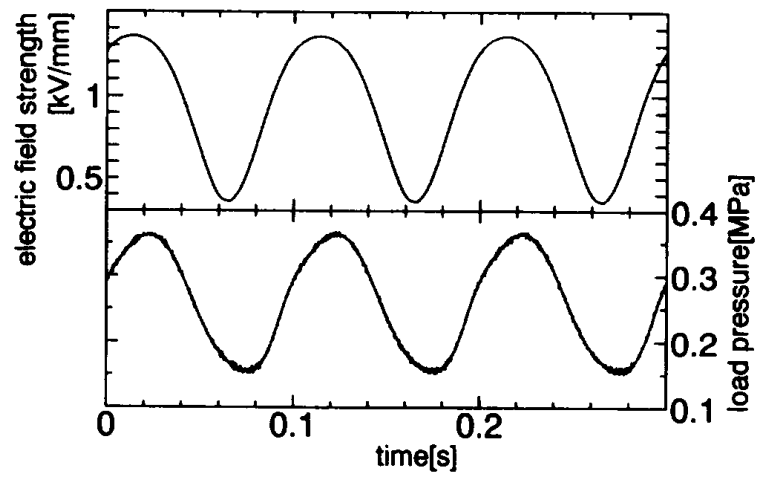

Fig. 13 Recorded waveforms with sinusoidal input $(10 \mathrm{~Hz})$ 


\section{4. アクチュエータ駆功例}

4.1 FHA 一神マニピュレータ 試作した圧力 制御 ER バルブを用いてアクチュエータとして横田ら が開発したコム人工筋 FHA(Flexible Hydraulic Actuator)(10)(11) の駆動を試みた. FHA は漏れと摺動 部がなく $\mathrm{ER}$ 粒子を破壞するおそれがまったくなく， また，FHA は内圧により制御されることから本実験 に採用した. FHA の動作は内王を上げると収縮し，下 げると FHA 自身のばね性により伸びる.図 14 に示す ように本研究ではこの直線運動をラック\&ピニオンに より回転運動に変え, 一軸のマニピュレータを構成し

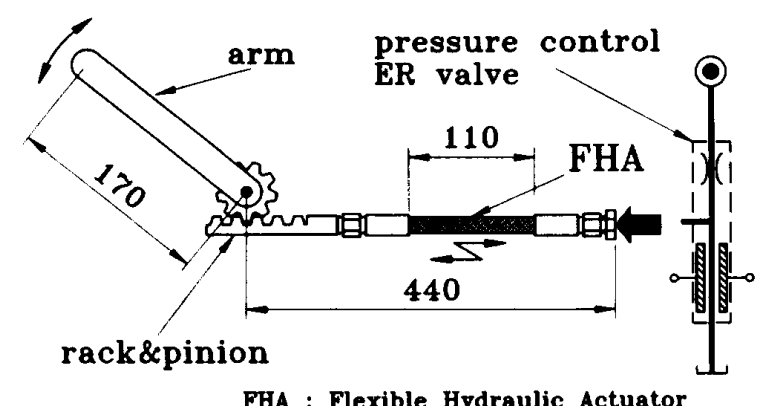

FHA : Flexible Hydraulic Actuator

Fig. 14 Schematic of the one-link manipulator by making use of FHA

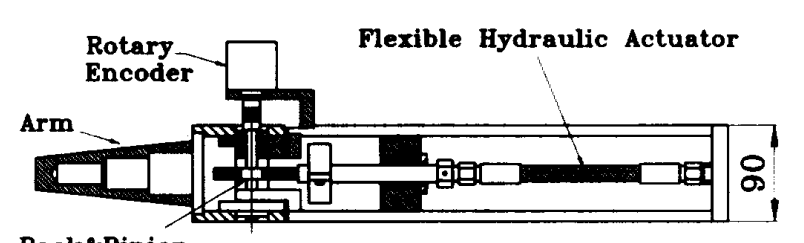

Rack\&Pinion

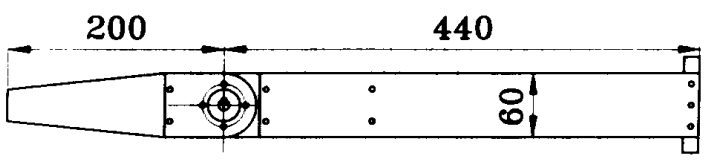

Fig. 15 The one-link manipulator by making use of FHA

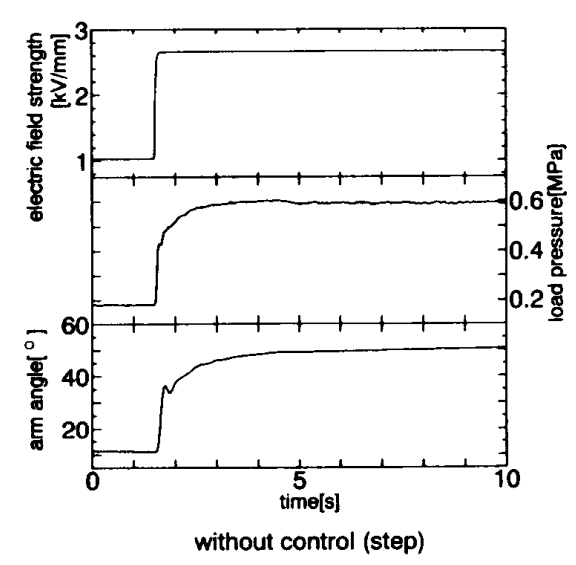

Fig. 16 Step response of the one-link manipulator (without control)
王力制御 $\mathrm{ER}$ バルブにより駆動した。図 15 に試作した FHA 一軸マニピュレータの概略を示す.アームの慣 性モーメントは $7.1 \times 10^{-3} \mathrm{~kg} \cdot \mathrm{m}^{2}$, また FHAの静特 性より，試作したマニピュレータを压力制御 $\mathrm{ER}$ バル ブで駆動した場合，最大トルクは概算で $2.5 \mathrm{~N} ・ \mathrm{~m}$ 程 度である。

$4 \cdot 2$ 殹結果 まず,サーボ系は構成せずに才 ープンループとし FHA 一軸マニピュレータの駆動を 試みた.ステップ状に圧力制御 $\mathrm{ER}$ バルフ電極間の電 界強度を変化させたときの, マニピュレータアーム角 度の応答波形を図 16 に示す.また, 同様に正弦波状に 変化させたときの結果を図 17 に示す.参考までに負荷

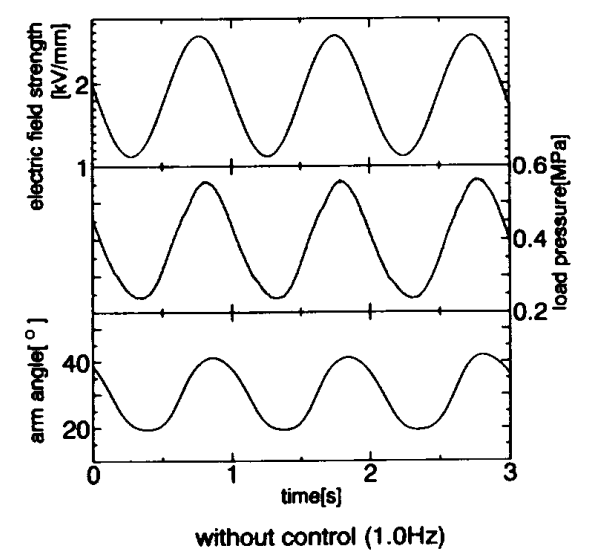

Fig. 17 Recorded waveforms with sinusoidal input (1.0 Hz, without control)

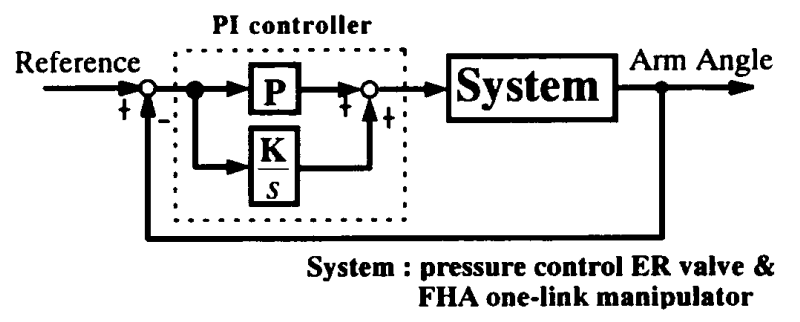

Fig. 18 Block diagram of servo system

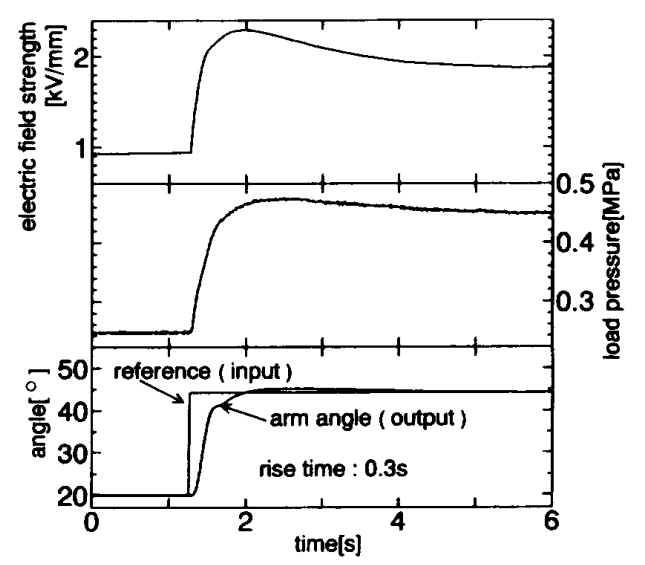

Fig. 19 Step response of the one-link manipulator (with PI control) 


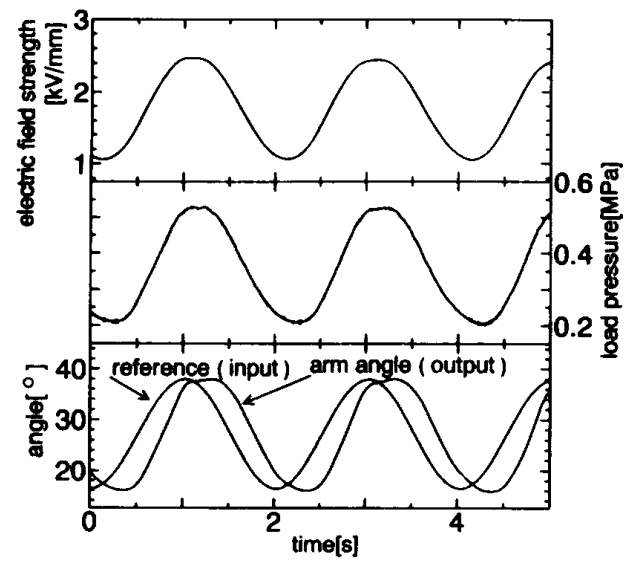

Fig. 20 Recorded waveforms with sinusoidal input $(0.5 \mathrm{~Hz}$, PI control)

圧力波形も示す．試作した圧力制御 $\mathrm{ER}$ バルブにより FHA 一軸マニピュレータを駆動することが可能であ ることが図16，17 の結果によりわかる.

$$
\text { 次にマニピュレータのアーム角度をフィードバック }
$$
したサーボ系を構成しアーム角度の制御を試みた。構 成したサーボ系を図 18 に示す.FHA は前述のように 定位性がある，そのため角度のフィードバックのみの 制御ではかなりの定常偏差を生じることから，本実験 ではPI 補偵をおこなっている。図19にサーボ系にス テップ入力したときのアーム角度応答波形を示す。ま た図 20 にサーボ系への入力を $0.5 \mathrm{~Hz}$ の正弦波とし たときのアーム角度の応答波形を示す，参考までに電 界強度波形および負荷圧力波形もそれそれの図に示 す.図 19 のアーム角度のステップ応答には若干のオー バシュートは見られるが定常偏差もなく, 立上り時間 $0.3 \mathrm{~s}$ 程度で応答しているのがわかる.この結果より試 作した圧力制御 $\mathrm{ER}$ バルブを用いて液圧サーボ系を構 成することが可能であることが実験により確かめられ た.

\section{5.あとがき}

粒子分散系電気粘性流体による 2 ポート ER バルフ の通過流量一差圧間の静特性を測定した。その結果, バ ルブ通過流量によらずほほ一定の差压を生じることか ら，粒子分散系電気粘性流体を用いた圧力制御 $\mathrm{ER}$ バ ルブを提案および試作した。得られた知見は以下のと おりである。

（1）試作した圧力制御 $\mathrm{ER}$ バルブは負荷流量によ らずほ隹一定した負荷圧力が容易に得られた。負荷圧
カとしては最高 $0.7 \mathrm{MPa}$ 程度まで得られた。

（2）試作した圧力制御 ER バルブの周波数特性を

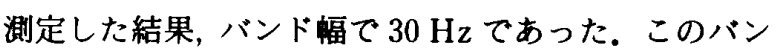
ド幅は液圧サーボ系への応用も可能である.

（3）試作した压力制御 ER バルブを用いて実際に FHA 一軸マニピュレータを駆動した。また，サーボ系 を構成しアーム角度の制御を行い，試作した圧力制御 $\mathrm{ER}$ バルブにより液圧サーボ系を構成することが可能 であることを実験により示した。

最後に日頃ご意見をいただいた東工大精研助手の吉 田和弘氏に深く謝意を表す。また粒子分散系電気粘性 流体を提供していただいた藤倉化成(株)および電気粘 性流体に関して数多くご助言いただいた当時，藤倉化 成(株)の枝村一弥氏に深く感謝する。また, FHA の作 製にあたっては日立電線 (侏) の大塚隆夫氏にご助力い ただいたことに深く感謝する。

\section{文献}

(1) Otsubo, Y. and Edamura, K., Electrorheological Properties of Suspensions of Inorganic Shell/Organic Core Composite Particles, J. Colloid Interface Sci., 168 (1994), 230-234.

(2) Strandrud, H. T., Electric-field valves inside cylinder control vibrator, Hydraulics \& Pneumatics, (1966-9). $139 \cdot 143$.

(3) Simmonds, A. J., Electro-rheological valves in a hydraulic circuit, IEE Proceedings-D, 138-4 (1991), 400-404.

（4）田中豊・坪江宏明, 人工筋肉取動用奄気粘性流体アクキュ エー夕の開発，機論, 60-579, C (1994), 296-301.

（5）小林博栄・小林信之・横井領・斉藤鿍・森下信, ER 流体 を用いた減衰力可変ダンパの基本特性，機論，59-566，C (1993), 102-106.

（6）石川誠・青山藤詞郎・枝村一弥・都築良㢁，ER 流体を纫 用した工作機械テーブルシステムの動特性向上， 62-593， C (1996), 326-332.

(7) Bullough, W. A. and Johnson, A. R., ほか 3 名, The electro-rheological clutch, Proc. Instn. Mech. Engrs. Part 1, 207 (1993), 87-95.

（8）例之ば，築地徹浩・高橋淳・杉本旭・池田博康，平行二平 板車極間の ERF の流れ特性, 油圧と空気圧, 25-4 (1994), $556-561$.

（9）例えば, Ugaz, V. M., Majors, P. D. and Miksad, R.W., Measurements of Electrorheological Fluid Flow through a Rectangular Channel Using Nuclear Magnetic Resonance Imaging. Developments in Electrorheological Flows and Measurement Uncertainty, FED205/AMD-190 (1994), 15-27, ASME.

（10）横田真一・小松健浩，宇宙眀境マニピュレータ用フレキシ ブ・ハイドロウリック・アクチュエータ, 機論, 57-542, C(1991), 3222-3229.

（11）横田真一・小松健治，FHAを応用したマニピュレータア 一公の制御, 機論, 59-567, C (1993), 156-162. 